\title{
Leder til temanummer Cutting Edge Kulturskole
}

Når vi for over ett år siden inviterte forskere til å skrive i JASEd visste vi at vi ønsket artikler som utvikler forskningsfronten, er 'on the edge', når det gjelder forskning på kunstfagene, kroppsøving og idrett i skole- og utdanningskontekst - og ulike tverrfaglige kombinasjoner. Nå er vårt første temanummer klart for publisering i januar 2017 etter lange prosesser med 'double blind' fagfellevurdering. Temanummeret som er redigert av Anna-Lena Østern og Elin Angelo, er knyttet til presentasjoner ved den kulturskolerelaterte forskningskonferansen "Cutting edge - kulturskole!» som ble gjennomført 27.-28.10. 2015 ved Dronning Mauds Minne høgskole for barnehagelærerutdanning med cirka 150 deltagere. I en konferanserapport ble 28 bidrag presentert. Av de artikler som har gjennomgått redaksjonell vurdering og deretter fagfellevurdering kan vi i temanummeret presentere fem artikler. Utover konferansetematikken inngår tre kunstfagdidaktiske artikler, som har blitt akseptert for JASEd av fagfeller, fordi de også kan ses som hørende til under paraplyen 'Cutting edge'.

Kunstfagene og idrettsfagene har noen felles trekk i fokus på kroppslig læring og forståelse, samt i konkrete prestasjoner og produkter innenfor begge profesjonsfeltene. JASEd har som målsetting å være i forskningsfronten når det gjelder kritisk analyse og presentasjon av forskning knyttet til undervisning, læring og kunnskapsproduksjon innenfor fagfeltene utfra problemstillingen: Hvordan kan kunstfagene og kroppsøvingsfagene bidra til transformasjon av utdanning for en holdbar fremtid?

Temanummeret innledes med en artikkel av Anne Berit Emstad og Elin Angelo: «Outsourcing av skolens musikkundervisningen - et bærekraftig samarbeid mellom kulturskole og grunnskole?»

Forfatterne analyserer et samarbeid mellom kulturskole og grunnskole, der kulturskolen har overtatt ansvaret for deler av grunnskolens musikkundervisning. Bakgrunnen for samarbeidet var et ønske om å styrke kvaliteten på musikkundervisningen i grunnskolen. Dette blir gjort gjennom å kjøpe ekspertise fra kulturskolen, og med det 'outsource' deler av grunnskolens undervisning. Artikkelen drøfter sentrale lederes refleksjoner i og om dette samarbeidet, speilet i teori om tverrsektorielt samarbeid.

I temanummerets andre artikkel «En musikers møte med de yngste barna i barnehagen» problematiserer Morten Sæther prosjektet Musiker i barnehagen, og 


\section{A.-L. Østern og E. Angelo}

fester oppmerksomheten ved den betydning samarbeid mellom kunstner og barnehagelærere har for dialogen med toddlere.

Anna-Lena Ostern har i den tredje artikkelen «Begrepet kunstnerisk kvalitet i den norske kulturskolens rammeplan - Mangfold og fordypning» gjort en kritisk diskursanalyse av verdigrunn, mål og kunnskapssyn i «Rammeplanen for kulturskolen i Norge- Mangfold og fordypning» sammenstilt med tilsvarende skisse til plan for grunnundervisning i kunst i Finland. Hun har fokusert på hvordan begrepet kunstnerisk kvalitet forstås i den norske rammeplanen fra 2016.

Gry Ulrichsen har i temanummerets femte artikkel, «Tenthaus Oslo - En inkluderende organisatorisk modell for framtidas kulturskoleelev» belyst et kunstnersamarbeid. Artikkelen retter også oppmerksomhet mot didaktiske forhold som kan øke deltakelsen av elever med heterogen kulturell bakgrunn i kulturskolen. I en videre forstand drøftes det hvordan kunstmøter i en pedagogisk kontekst kan få betydning i et demokratisk utviklingsperspektiv.

Heidi Haraldsen og Siri Ingul har i artikkelen «Negotiating Narrative Identity in Intercultural Contexts - the Role of Applied Theatre», innenfor rammen av prosjektet Udsnidt fokusert på kunstnerlæreres forståelse av bidrag gjennom solidaritetsforumteater. Tolkning og analyse av teori relatert til praksis avslører hvordan estetiske forhandlingsprosesser og iscenesettelse av livshistorier (narrativ) tilrettelegger for at deltakere får utforske, konstruere og rekonstruere, samt metareflektere over egen identitet.

I Volum 1 inngår også disse tre artiklene.

Kristian Knudsens studie «Performative læringsrum på digitale scener dramadidaktik og sociale medier» peker på mulig fornyelse av dramadidaktikk. Han skriver: Skolens laringsrum er udfordret gennem de sociale mediers konstante tilstedevarelse. Det kan vare vanskeligt for larere at håndtere, hvordan de sociale og digitale rum kan integreres $i$ undervisningen. Hensigten med denne studien er at undersøge, hvordan performative laringsrum opstår $i$ mødet mellem dramadidaktik og sociale medier.

Pauliina Maapalos artikkel «Vi rigger til så godt vi kan» - Konturer av praksisarkitekturer som muliggjør og hindrer undervisning i materialet tre i kunstog håndverksfaget $\mathrm{i}$ norsk barneskole» undersøker ved hjelp av en teori om praksisarkitekturer hvordan muligheter og hindringer for arbeid med tre i barneskolen oppstår i et dynamisk samspill mellom praksiser og praktikere (lærere på barneskolen), intersubjektive rom og praksisarkitekturer.

Hannah Kaihovirtas artikkel, "Teacher Improvisation as Processes of Mosaic, Kaleidoscope and Rhizome - an arts-based, co-teaching approach», bygger på en selvstudie av et kunstner-lærersamarbeid, og betydningen av improvisasjon i dette samarbeidet.

I volum 1 inngår også en anmeldelse av forskningsantologien «Edge», produsert av et nordisk nettverk innenfor visuell kultur.

Kunstfag og kroppsøvingsfaget i grunnskolen og grunnskolelærerutdanningen er samlet under den felles paraplyen praktiske og estetiske fag. Det er store ulikheter mellom fagene, både innad i og mellom kunstfagene slik de finnes i skole og opplæring, og i og mellom idrettsfagene og kroppsøvingsfaget i skole og samfunn. 
Disse ulikhetene poengteres og problematiseres blant annet i stortingsmelding 28, om fornyelse av kunnskapsløftet, og det påpekes av faggruppen praktiske og estetiske fag er utfordrende (Meld. St. 28, 2015-2016). Likevel foreslås denne enheten videreført, og begrepet praktiske og estetiske fag dekker da videre både kunstfagene og idrettsfagene. Selv om det er store ulikheter innad i og mellom fagområdene som presenteres i JASEd er det imidlertid også mange fellestrekk. Det ene gjelder sanselighet og kroppslig læring, og det er fruktbart å styrke en flerfaglig og tverrfaglig tilnærming i og mellom kunst- og idrettsfag for å videreutvikle forskning om dette. Skole og samfunn som helhet behøver mer forskningsbasert kunnskap om sanselig tilnærming til læring og såkalt alternative læringsrom. Dette er emner som det fokuseres på i flere av artiklene i JASEd. Et annet fellestrekk gjelder profesjonsfeltet og profesjonsforståelsen. Profesjonsfeltet for kunst- og kroppsøvingslærere er ofte både i og rundt skolen, både når det gjelder yrkeslivet og i utdanningen. Den samme utøverlæreren jobber gjerne både i kultur/idrettslivet, i kultur/idrettsopplæring og i både grunnskole, videregående skole og kulturskole. Forskning om yrkes- og utdanningspraksis, utvikling av rolleforståelser og profesjonskunnskap behøver å ta nettopp slike profesjonsrealiteter som utgangspunkt. Et tredje fellestrekk er forholdet mellom bredde og talentutvikling som er sentralt både innenfor kunstfag og idrett. Et fjerde trekk gjelder mesterlæretradisjonen og de uformelle kvalifiseringsveiene som gir tilgang til yrkesutøvelser innen både kunstpedagogikk og idrettspedagogikk. Samarbeid og dialog i forskningsfeltet, som i JASEd, styrker, utfordrer og utvikler kunnskap om disse fire trekkene - på tvers av kunstfag og idrettsfag.

Når leseren nå kan ta del av vårt første temanummer, står det andre temanummeret klart for publisering forhåpentlig i mars 2017, «Kroppsøvingskonferansen 2016» med Jorunn Spord Borgen og Kjersti Mordal som redaktører. Nye temanummere er planlagt fra Kroppsøvingskonferansen $\mathrm{i}$ juni 2017, og fra «Cutting edge»-konferansen $\mathrm{i}$ oktober 2017. Et spesialnummer «A forske med kunsten - metodologiske perspektiver» er også under planlegging med Tone Østern som redaktør.

Anna-Lena Østern og Elin Angelo Redaksjonen for JASEd 